\title{
Lecturers' Perception of Constraints Facing the Teaching of Entrepreneurship Education in Colleges of Education in South South Nigeria
}

\author{
James Okoro ${ }^{1, *}$ \\ ${ }^{1}$ Institute of Education, Delta State University, Abraka, Nigeria \\ *Correspondence: Institute of Education, Delta State University, Abraka, Nigeria. E-mail: jimkorokpeu@yahoo.com
}

Received: May 17, 2014

Accepted: June 18, 2014 Online Published: June 8, 2015

doi:10.5430/wje.v5n3p99

URL: http://dx.doi.org/10.5430/wje.v5n3p99

\begin{abstract}
The study investigated the constraints facing the teaching of entrepreneurship education in colleges of education in South South Nigeria. A research question was raised and three hypotheses were formulated for the study. A descriptive survey design was used for the study. The population which also served as sample comprised 206 Business Education lecturers. The researcher used a questionnaire which has 24 items. The content and face of the instrument was validated by experts in business education and measurement and evaluation. The questionnaire has a reliability value of 0.92 using Cronbach alpha. Mean score and standard deviation were used to answer the research question while t-test was used to test the hypothesis at 0.05 level of significance. The findings are ineffective monitoring, ineffective evaluation, insufficient time, poor welfare package and inadequate teaching facilities are some of the constraints facing the teaching of entrepreneurship education in colleges of education. It was, therefore, recommended that adequate teaching facilities should be provided by the school authorities to enhance quality teaching of entrepreneurship education. Adequate teachers should also be employed by school authorities.
\end{abstract}

Keywords: constraints; teaching; entrepreneurship education, business education; colleges of education, Nigeria

\section{Introduction}

Business Education which is a branch of the general education programme falls within the spectrum of vocational education. Jimoh-Kadiri and Bupo (2011) describe Business Education as the transfer of pedagogical and business competencies necessary for teaching business attitudes, concepts, skills and knowledge. Therefore, Business Education is that aspect of educational training which an individual receives with the primary motive of enabling him to acquire adequate attitudes, concepts, knowledge, understanding and skills in business activities for vocational usage in careers as an administrator, manager or teacher wherever he may find himself in the business world. Ulinfun (1986) in Dibbari and Ibe (2012) defined business education as education for and about business or training in business skills and competencies for use in business office, clerical, occupations and business policy analysis. Osuala (2004) describe business education is a programme of instruction which consists of two parts: (1) office education; a vocational programme, office careers through initial refreshers and upgrading education and general business education; a programme meant to provide students with information and competencies which are needed by all in managing personal business affairs and using the services of the business. In the same vein, Chibuike (2013) points out that Business Education involves teaching students the fundamentals, theories and processes of business. Business Education typically prepares students for an occupation in business or a business related field or a teaching career in academics.

According to Aliyu (2006), the objectives of Business Education include the following:

- $\quad$ To develop a mature understanding of the general nature of business

- To provide the needed background for teaching in business subjects

- To provide training in specialized phases of business activity

- To lay a cultural and ethical foundation for the development of the fore-going objectives. 
In secondary school business Education is called business study which has five major components namely book keeping, office practice, commence, typewriter and shorthand. In college of education and universities business education is offered as a programme of study. Business education at tertiary education level is offered primarily to meet the manpower needs of the country in the various business trades, develop a culture of leadership in them as well as acquaint them with advanced skills that would enable them to perform as managers, entrepreneurship, and consultants in any business setting (Asuquo, 2012). Azuka, Nwosu, Kanu and Agomuo (2006) in Asuquo (2012) stated that the business teacher education programme in the universities is established to train competent business teachers who are capable of promoting and enriching business education programmes at the secondary and other levels of post-secondary education in the country.

The structure of business education in colleges of education is a different from what it is offered in universities. Nigeria established the National Commission for Colleges of Education (NCCE) in the 1989 Education Act and the Amendment Act 12 of 1993, was for a primary mandate of supervising higher education in the country, in line with the utmost importance accorded to quality teacher education, Business Education teachers inclusive, by the Federal Government (FRN, 2013).Business Education teachers, therefore, must be well equipped to carry out this responsibility of quality assurance in education. Badmus (2005) maintains that for education to be qualitative, the teacher who is the instrument of transfer must first be qualitatively equipped to perform the task.

The philosophy of Business Education in Colleges of Education is to make the Business Educators understand the concept and philosophy of the National Policy on Education as regards Business Education in national development. The following are the objectives:

o Well qualified and competent NCE graduates in business subjects who will be able to teach these subjects in our secondary schools and other related educational institutions,

o NCE business teachers who will be able to inculcate the vocational aspects of Business Education into the society,

o NCE Business Teachers who will be involved in the much desired revolution of vocational development right from the Primary and Secondary schools,

o Students who are equipped with necessary competencies so as to qualify them for a post NCE degree programme in Business Education,

o Graduates who are equipped with the right skills that will enable them to engage in a life of work in the office as well as for self-employment (FRN, 2013).

Business Education is divided into accounting and secretarial studies in college of education. Entrepreneurship education is a compulsory course to all business education students. Students, on graduation, are expected to have acquired the necessary skills, knowledge and attitude to enable them set up their own businesses and run them successfully. The emphasis of government today is on entrepreneurship education. This is the training given to students in education to enable them set up their own businesses without depending on white collar-jobs. The National Commission for Colleges of Education (2004) has introduced entrepreneurship education as a compulsory course for every student in colleges of education. In Business Education, there are several courses in entrepreneurship education that all students are expected to take and pass before graduation.

Entrepreneurship as a concept refers to a business owned, managed, controlled and financed by an individual. It is also called sole proprietorship. The principal motive of every business is profit maximization as well as development of human and material resources for provision of goods and services for mankind. According to Ani and Nwandu (1999), entrepreneurship has been recognized as an essential ingredient of economic development. Economic development in the advanced or industrialized nations has in many cases been initiated by the emergence of entrepreneurial studies. Business generally has been described by different writers but with one concept. It refers to the various activities in which people engage so as to earn a living. Onuoha (1998) defines business as a set of activities in which a person working alone or in a group tries to produce and distribute the goods which are important for the comfort and general well-being of people and the society. Technology is advancing at a very high speed and the only way a nation can cope with globalization is to initiate productive and service oriented ventures that can compete favorably with other nations. This can only be achieved through providing entrepreneurial studies that will enhance self-sustenance and employment as well as economic development.

The current massive unemployment of both youths and adults as a result of global economic recession has caused the federal government to lay emphasis through several programmes and agencies on the need for all Nigerian citizens to strive for self-reliance through self-employment. This has led the government to establish the National Directorate of 
Employment (NDE) which has set up the entrepreneurial education or programme in Nigeria. This programme now cuts across all sectors of learning where students are intimated with the necessary tools for self-reliance and employment.

Ugwu (2012) stated that entrepreneurship education is that type of education tailored towards producing a self-employed or self-reliant person. It aims at innovation, ingenuity, resourcefulness and endurance. The entrepreneurship education is meant to enable the Nigerian child overcome the problem of unemployment and business challenges. Ugwu, (2012) stating FRN (2004) observed that national policy on education states one of the goals of technical and vocational education is to give training and impart the necessary skills to the individuals who shall be self-reliant economically. Okoro and Ofishe (2011) defined entrepreneurship as a process of running a business of one's own. Ogbonyomi (2012) stated that entrepreneurship refers to the attitude, skills and actions of an individual starting a new business. The Irish Business and Entrepreneurship Survey (2003) defined an entrepreneurship as an owner and/or principal manager responsible for the expansion and strategic development of a business. An Entrepreneur is anyone who owns, operates and takes the risk of a business. He is a person who takes on the responsibility of providing services or values upon identifying a market opportunity or gap with the expectation of profit making (Ogbonyomi, 2012). Okoro and Ofishe, (2011) added that an entrepreneur has the ability to see and assess business opportunities even where others cannot, and it able to combine natural resources, human input, physical assets, intelligence and creativity to achieved goals. It also involves identifying and exploiting entrepreneurial opportunities in business.

Entrepreneurship refers to the attitude skills and characteristics that predispose an individual or individuals towards starting a business venture. Olise (2010) defined entrepreneurship as the process of creating value by putting together a unique package of resources to exploit an opportunity. It is the willingness and ability of an individual (or group of individuals) to seek out investment opportunities especially through innovation to establish and run an enterprise successfully.

Frankie-Dolor (2010) stated that an entrepreneur is a creative person and a risk bearer who is good at recognizing an opportunity, analyzing it, and making a decision to act upon it, but marshalling necessary resources, and implementing a programme leading to a new enterprise and profit. Even though the business may be small, he or she needs managerial, analytical thinking, marketing, accounting, finance and manufacturing skills to succeed. This means that the entrepreneur requires personal skills and judgment as well as ability to work with people with patience and endurance. Entrepreneurship is an attempt to create value by an individual or individuals through the identification of significant innovative and business opportunity. The drive to manage risk take risk appropriate to the project and exercise communicative and managerial skills necessary to mobilize human, materials and financial resources is central to business success. Entrepreneurship therefore incorporates risks, uncertainty, innovation perception and change (Olise, 2010).

Entrepreneurship is an ability of an individual to seek out investment opportunities, establish and run an enterprise successfully as quite distinct from obtaining a paid job. Entrepreneurship, according to Daboer (2011) quoting U.S. Colorado Education, is a programme or part of the programme that prepares individuals to undertake the formation and or operation of small-scale business which includes franchise to operates for the purpose of performing all business functions relating to a product or service, with emphasis given to the social responsibilities, legal requirements and risk for the sake of profit involved in the conduct of a private business.

Entrepreneurship as a concept can be perceived from the following perspectives: as an ability to start a business, as leadership qualities of carrying on business, as an ability to organize a entrepreneurship, as the ability to start or organize commercial enterprise, especially one involving a financial risk. Some of the Entrepreneurship skills are self-motivation; self-confidence; ethics and morals, time management, sales, finance, ability to take risk, positive leadership qualities, originality and hard work. These qualities are necessary in starting and sustaining a business enterprise, the absence of which jeopardizes the chances of succeeding in a business undertaking despite the huge amount invested in it.

Entrepreneurship education according to Osuafor, Okeke and Nnorom (2010) in Ubogu (2013), can be said to be an education that prepares and equips individuals with entrepreneurial skills that will enable one start off a business for wealth creation. According to Paul (2005) in Arogundade (2011) the objectives of entrepreneurship education include:

- To offer functional education for the youth that will enable them to be self-employed and self- reliant. 
- To provide the youth graduates with adequate training that will enable them to be creative and innovative in identifying novel business opportunities.

- To serve as a catalyst for economic growth and development.

- To offer tertiary institution graduates with adequate training in risk management.

- To reduce high level of poverty.

- To create the process of employment generation.

- To reduce rural-urban migration.

- To provide the young graduates with enough training and support that will enable them to establish a career in small and medium sized businesses.

- To include the spirit of perseverance in the youths and adults which will enable them to persist in any business venture they embark on.

- To create smooth transition from traditional to a modern industrial economy.

Ejili (2013) identifies the following constraints facing the quality of teaching in entrepreneurship education in Nigeria: inadequate curriculum provision, ineffective monitoring and evaluation, inadequate and unqualified personnel, poor welfare package, poor infrastructure, excess carrying capacity, poor funding, no quality assurance department, unwillingness of industries to partner with higher institutions offering entrepreneurship education and frequent change of leadership. Ubogu (2013) identifies some constraints facing the teaching of entrepreneurship in higher institutions: inadequate teaching facilities, inadequate libraries, inadequate infrastructure, inadequate laboratories and workshops. Azuka \& Azuka (2013) also note the constraints to include: compartmentalization along faculty and school lines, problem of awareness and motivation within the institutions, inadequate human and financial resources, clear mismatch of funding to the demand for entrepreneurship studies and paucity of teaching staff.

\section{Statement of the Problem}

Some of the challenges facing quality of teaching in entrepreneurship education in tertiary institutions in Nigeria include lack of facilities for proper training, for acquisition of entrepreneurial skills. These facilities, according to Gyuse (2009), include adequate teaching materials, equipment, laboratories and workshops. Many schools do not have libraries and even when they exist, most of them have no science and business text books. These facilities are necessary in schools because as Ehiametalor (2001) observes, students learn better when facilities like building, comfortable seats for teachers and students are available. However, the situation is not so in our schools. NUC (2006) reports that facilities in Nigerian universities are in poor shape, the available physical facilities are severely overstretched and ill maintained. Hence, with this development quality seems not to be guaranteed in entrepreneurship education in Nigeria.

The problem of the study is, therefore, what are the constraints facing the teaching of entrepreneurship education in colleges of education in south south Nigeria?

\section{Purpose of the Study}

The purpose of the study was to assess the constraints facing the teaching of entrepreneurship education in college of education in south south Nigeria.

\section{Research Question}

The following research question was raised to guide the study.

What are the constraints facing the teaching of entrepreneurship education in colleges of education?

\section{Hypotheses}

The following hypotheses are to guide the study.

1) There is no significant difference between male and female Business Education lecturers mean rating on the constraints facing the teaching of entrepreneurship education in colleges of education. 
2) There is no significant difference between state and federal colleges of Education lecturers mean rating on the constraints facing the teaching of entrepreneurship education in colleges of education.

3) There is no significant difference between experienced and less experienced lecturers mean rating on the constraints facing the teaching of entrepreneurship education in colleges of education.

\section{Method}

The design of study was a descriptive survey. The population which also served as sample comprised 206 Business Education lecturers in public colleges of Education in the south south, Nigeria. The questionnaire was an instrument used for data collection. The questionnaire had 24 items. It was divided into two parts: Part A of the questionnaire had 4 items concerning the respondents (name of school, sex, school type, job experience). Part B had 20 - items based on the research question. The questionnaire was structured on a four-point scale of Strongly Agree (SA), Agree (A), Disagree (D) and Strongly Disagree (SD). The questionnaire was validated by four experts in Business Education and three experts in Measurement and Evaluation. The observations made and corrections recommended by the validates were effected and incorporated in the final copy of the instrument which was reproduced for administration to the subjects. The questionnaire was also validated using factor analysis. The questionnaire was administered to 25 Business Education lecturers in Colleges of Education in south east Nigeria which was not part of the study. This helps determine the reliability of the instrument. The data collected were analyzed using Cronbach alpha and a reliability coefficient of 0.92 was obtained. The mean score and standard deviation were used analyzed the data. The response options were weighted as follows: Strongly Agree - 4points, Agree - 3points, Disagree 2points, Strongly Disagree -1 point. A benchmark of 2.50 was set to accept or reject items on the questionnaire. Mean score above 2.50 showed accepted, while mean score less than 2.50 showed rejected. T-test statistics was used to test the hypotheses at 0.05 level of significance. If the calculated value (CV) is less than table value (tv) 1.96, the hypothesis is upheld, if t-calculated (tc) is above table value (tv), the hypothesis is rejected.

\section{Result}

\subsection{Research Question}

What are the constraints facing the teaching of entrepreneurship education in colleges of education?

Table 1. Mean Ratings and Standard Deviation of Business Education Lecturers on the Constraints Facing the Teaching of Entrepreneurship Education in Colleges of Education

\begin{tabular}{clccc} 
(N=206) & & & & \\
\hline s/n & Constraints facing entrepreneurship education & Mean & SD & Remark \\
\hline 1 & Inadequate curriculum provision & 277 & 0.81 & Accepted \\
2 & Ineffective monitoring & 2.74 & 0.88 & Accepted \\
3 & Ineffective evaluation & 2.66 & 0.73 & Accepted \\
4 & Insufficient time & 2.79 & 0.90 & Accepted \\
5 & Inadequate teachers & 2.86 & 0.77 & Accepted \\
6 & Unqualified teachers & 2.30 & 0.82 & Rejected \\
7 & Poor welfare package & 2.93 & 0.74 & Accepted \\
8 & Poor infrastructure & 2.95 & 0.69 & Accepted \\
9 & Inadequate laboratories & 3.00 & 0.86 & Accepted \\
10 & Excess carrying capacity & 2.83 & 0.91 & Accepted \\
11 & Insufficient classrooms & 2.98 & 0.79 & Accepted \\
12 & Poor funding & 3.05 & 0.74 & Accepted \\
13 & Failure to get students enthusiastic for the course & 2.58 & 0.87 & Accepted \\
14 & Misconception of entrepreneurship education & 2.70 & 0.98 & Accepted \\
15 & Lack of innovations in teaching & 2.56 & 0.89 & accepted \\
16 & Lack of cooperation among departments & 2.66 & 0.78 & Accepted \\
17 & Lack of committed lecturers & 2.10 & 0.75 & Rejected \\
18 & Lack of awareness of entrepreneurship education & 2.74 & 0.85 & Accepted \\
19 & Compartmentalization along faculty lines & 2.78 & 0.96 & Accepted \\
20 & Lack of support from government & 2.84 & 0.80 & Accepted \\
& Grand mean & $\mathbf{2 . 7 8}$ & $\mathbf{0 . 8 0}$ & Accepted \\
\hline
\end{tabular}


The table presented reveals that, all the items except item 6 and 17 are Constraints facing teaching of entrepreneurship education since the mean ranges from 2.5 and above.

\subsection{Testing of Hypotheses}

1. There is no significant difference between male and female Business Education lecturers mean rating on constraints facing teaching of entrepreneurship education.

Table 2. T-test Mean Rating of Male and Female Business Education Lecturers Mean Rating on Constraints Facing Teaching of Entrepreneurship Education

\begin{tabular}{cccccccccc}
\hline $\begin{array}{l}\text { Variable } \\
\text { categories }\end{array}$ & $\mathrm{N}$ & $\mathrm{X}$ & $\mathrm{SD}$ & $\mathrm{Df}$ & $\mathrm{t}$ - Cal & $\mathrm{t}$ - Crit & $\begin{array}{l}\text { Level } \\
\text { Sign. }\end{array}$ & Dec. & Remark \\
\hline Male lecturers & 117 & 2.86 & 0.82 & & & & & & \\
Female lecturers & 89 & 2.70 & 0.80 & 204 & 1.24 & 1.96 & 0.05 & NS & Accepted \\
\hline
\end{tabular}

$* \mathrm{P}<0.05$

Computed t-value (1.24) is less than 1.96 at 0.05 level of significance. The hypothesis earlier stated is therefore upheld.

2. There is no significant difference between state and federal colleges of education Business Education lecturers mean rating on constraints facing teaching of entrepreneurship education.

Table 3. T-test Mean Rating of State and Federal Colleges of Education Business Education Lecturers Mean Rating on Constraints Facing Teaching of Entrepreneurship Education

\begin{tabular}{lccccccccr}
\hline $\begin{array}{l}\text { Variable } \\
\text { categories }\end{array}$ & $\mathrm{N}$ & $\mathrm{X}$ & $\mathrm{SD}$ & $\mathrm{Df}$ & $\mathrm{t}-$ Cal & t- Crit & $\begin{array}{c}\text { Level } \\
\text { Sign. }\end{array}$ & Dec. & Remark \\
\hline State lecturers & 119 & 2.95 & 0.86 & & & & & & \\
Federal lecturers & 87 & 2.81 & 0.74 & 204 & 1.084 & 1.96 & 0.05 & NS & Accepted \\
\hline
\end{tabular}

$* \mathrm{P}<0.05$

Computed z-value (1.084) is less than 1.96 at 0.05 level of significance. The hypothesis earlier stated is therefore upheld.

2. There is no significant difference between experienced and less experienced lecturers mean rating on constraints facing teaching of entrepreneurship education in colleges of education.

Table 4. T-test Mean Rating of Experienced and Less Experienced Lecturers Mean Rating on Constraints Facing Teaching of Entrepreneurship Education

\begin{tabular}{lccccccccc}
\hline Variable categories & $\mathrm{N}$ & $\mathrm{X}$ & $\mathrm{SD}$ & $\mathrm{Df}$ & $\mathrm{t}-$ Cal & t- Crit & $\begin{array}{c}\text { Level } \\
\text { Sign. }\end{array}$ & Dec. & Remark \\
\hline Experienced lecturers & 152 & 2.85 & 0.80 & & & & & & \\
Less experienced lecturers & 54 & 2.74 & 0.76 & 204 & 0.938 & 1.96 & 0.05 & NS & Accepted \\
\hline
\end{tabular}

$* \mathrm{P}<0.05$

Computed z-value (0.938) is less than 1.96 at 0.05 level of significance. The hypothesis earlier stated is therefore upheld.

\section{Discussion}

The study revealed the constraints facing teaching of entrepreneurship education such as inadequate curriculum provision, ineffective monitoring, ineffective evaluation, insufficient time, poor welfare package, poor infrastructure, inadequate laboratories, excess carrying capacity, insufficient classrooms, Poor funding, failure to get students enthusiastic for the course, misconception of entrepreneurship education, lack of innovations in teaching, lack of cooperation among departments, lack of awareness of entrepreneurship education, compartmentalization along faculty lines and lack of support from government. This study is consistent with the earlier studies of Ubogu (2013), Ejili (2013), Azuka and Azuka (2013) who identified constraints facing the teaching of entrepreneurship education in 
tertiary institutions in Nigeria. The results of the hypotheses also reveal that there is no significant difference between male and female Business Education lecturers on their mean rating on the constraints facing the teaching of entrepreneurship education in colleges of education, there is no significant difference between state and federal colleges of Education lecturers on their mean rating on the constraints facing the teaching of entrepreneurship education in colleges of education and there is no significant difference between experienced and less experienced lecturers on their mean rating on the constraints facing the teaching of entrepreneurship education in colleges of education.

\section{Conclusion}

Entrepreneurship education helps in developing entrepreneurial drive among students; training students in what is needed to identify and exploit business opportunities. Adequate instructional facilities and human resources are highly needed in colleges of education to impart the necessary skills, knowledge, attitude to the students to enable them be self-employed after graduation. Therefore, effective cooperation between higher education institutions, teachers, students and enterprises for achieving greater result.

\section{Recommendation}

The following recommendations are suggested.

1. Adequate teachers should be employed by school authorities.

2. Adequate laboratories should be provided.

3. Sufficient fund should be allocated to the entrepreneurship programmes.

\section{References}

Aliyu, M.M. (2006). Business education in Nigeria: Trends and issues. Ilorin: Ghosen Print Media.

Ani, N.B., \& Nwandum, E.C. (2007). Entrepreneurial Management. Enugu: NERCE Publication.

Anyanwu, A. (1999). New perspective of entrepreneurial development. Owerri: Klet-ken Publisher.

Arogundade, B.B. (2011). Entrepreneurship Education: An Imperative for sustainable development. Journal of emerging trends in educational research and policy studies (JETERAPS), 2(1), 26-29.

Asuquo, E.E. (2012). Fundamental issues impeding business education in achieving sustainable national economy. Nigerian Vocational Association Journal, 17(1), 206-215.

Azuka, E.B., \& Azuka M. O. (2013). Entrepreneurship education in Nigeria's tertiary institutions: challenges and strategies to achieve efficiency. Association of Business Educators of Nigeria, 3(1), 282-294.

Azuka, E.B., Nwosu, B.O. Kanu, I.N., \& Agomuo, E.E. (2006). Foundations of business education in Nigeria. Oko; Dataword computers academy.

Badmus, S.G. (2005). Issues, organization and administration of examination in Nigeria. In Lassa, P.N., \& Aghenta, J.A. (eds.), Proceeding of the $16^{\text {th }}$ Annual Congress of the Nigerian Academy of Education. Jos. University of Jos.

Chibuike, V.C (2013). Analysis of quality assurance in Business Education: the perception of business teachers in Enugu State junior secondary schools. Nigerian Journal of Business Education, 1(2), 49-56.

Daboer, D.G. (2011). Entrepreneurship and functional vocational education: a catalyst for the realization of national objectives of vision 2020 in Nigeria. Multidisciplinary: Journal of Research Development, 17(1), 128-133.

Dibbari, J.C., \& Ibe E.O. (2012). Challenges facing evaluation of business education. Books of Readings, 2(1), 105-109.

Esene, R.A. (2009). Research in Education. Agbor: Royal Pace Publications.

Federal Republic of Nigeria (2004). National policy on education. Lagos. NERDC Press.

Federal Republic of Nigeria (2013).Minimum standards for NCE teacher (vocational/Technical education). Retrieved from blueprinting.com/new/ncce-and-teacher education-in-nig.On 16/08/2013

Frank-Dolor, R.T. (2010). Entrepreneurship development, concept, theory and practice in business management. 
Ugregha Nig. Company.

Gyuse, E.Y. (2009). Moving teaching and science education forward. Diagnosing science teacher problems. In Nsikak-abasi Udofia (Ed).Annual conference of Stan. HBN Publishers Plc. 3-20.

Jimoh-Kadiri, S.O., \& Bupo, G.O. (2011). Challenges facing e-learning in teaching business education courses: strategies for improvement. Orient Journal of Education, 6(1 \& 2), 163-169.

Momoh, A.O. (2008). Sustenance of Nigerian content development through entrepreneurship education. The Nigerian Institute of Mechanical Engineers.

National Commission for Colleges of Education (2008, Nov. 9). Weekly bulletin, 4(6), 2.

National Universities Commission (2006). Webomatric Ranking of world universities matters arising. Monday Memo NUC, Abuja, 5(11), 1-10.

National Universities Commission (2007). Quality assurance in Nigerian universities. ranking of universities according to performance of their academic programmers. Abuja: NUC.

National Universities Commission (2007). Quality Assurance in Nigerian Universities. Ranking of Universities according to performance of their academic programmers. Abuja: NUC.

Ogbonyomi, O.B. (2011). Basic nutrition for the tropics. Benin: Masega publishers.

Okoro, E.N., \& Ofishe, W.O. (2011). Practical entrepreneurship. Benin: Minder publisher.

Olise, J.M. (2010). Entrepreneurship: a conceptual approach. Lagos: Concept Publications Nig. Ltd.

Osuafor, A.M., Okeke, S.O., \& Nnorom, N.R. (2010). Strategy and Challenges to Entrepreneurship Education in science for sustainable development. Unizik Orient Journal, 1, 30-37.

Osuala, E.C. (2004). Principles and practical computer education. Enugu State. Cheston Agency Ltd.

Ubogu, R.E. (2013). Quality assurance in entrepreneurship education: a strategic option for national development. Association of Business Educators Nigeria, 3(1), 240-245.

Ugwu, E.N. (2012). Strategies for improving national economy through entrepreneurship education in the home economics. Nigerian Vocational Association Journal, 17(1), 216-223.

Ugwuoke, F.N. (2011). Entrepreneurial issues for a functional Business Education. Towards the attainment of national education goals: Multidisciplinary. Journal of Research Development, 17, 84-88.

Ulinfun, F.E. (1986). Business education, utility education in a developing economy. Business Education Journal, $1(1)$. 